\title{
Analysis of Rainfall Seasonality Index in Iraq
}

Hasanain K. A. AL-Shamarti

\section{Analysis of Rainfall Seasonality Index in Iraq}

\author{
Hasanain K. A. AL-Shamarti \\ Department of Atmospheric Sciences- Collage of Sciences- AL-Mustansiriyah University- Baghdad- \\ Iraq
}

Received: 28 March 2016

Accepted: 23 May 2016

\begin{abstract}
$\underline{\text { Abstract }}$
The Rainfall Seasonality Index $(R S I)$ is used to study the spatial and temporal change in rainfall behavior in that contribute in improvement of water and management plans of water resources systems and agriculture in a certain region especially during dry seasons. Rainfall date is obtained for twenty-eight weather stations in Iraq to find the seasonality index for each station. To give a clear conception of rainfall regime, the study area is divided to three zone according to amount rainfall. The results described the rainfall regime and showed that $R S I$ of study area is noticed at ranges $(0.60-0.79),(0.80-0.99),(1.0-1.99)$ and $(1.20<)$. The range (1.0-1.99) is most frequent in southern and middle regions whereas the range $(0.80-0.99)$ is most frequent in northern zone. The results shows that RSI has significant variation form zone to other and obviously fluctuations from year to year through the study period.
\end{abstract}

Key words: Seasonality, Rainfall, Climate, Iraq.

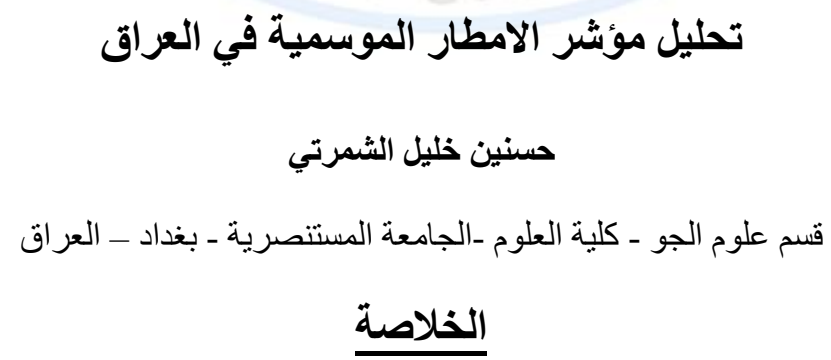

يستخدم مؤشر الموسمية لدراسة التغير الزماني والمكاني في سلوك الامطار والني تساهم في تحسين خطط ادارة المياه بالنسبة للانظمة الزر اعية ومصادر المياه خلال فترات الجفاف لمنطقة معينة . استخدمت بيانات الامطار لـ 28 محطة انو ائية في العر اق لايجاد مؤشر الموسمية لكل محطة ـ قسمت منطقة الدراسة الى ثلاث مناطق وفقا لكميات الامطار الساقطة لفهم 


\section{Analysis of Rainfall Seasonality Index in Iraq}

\section{Hasanain K. A. AL-Shamarti}

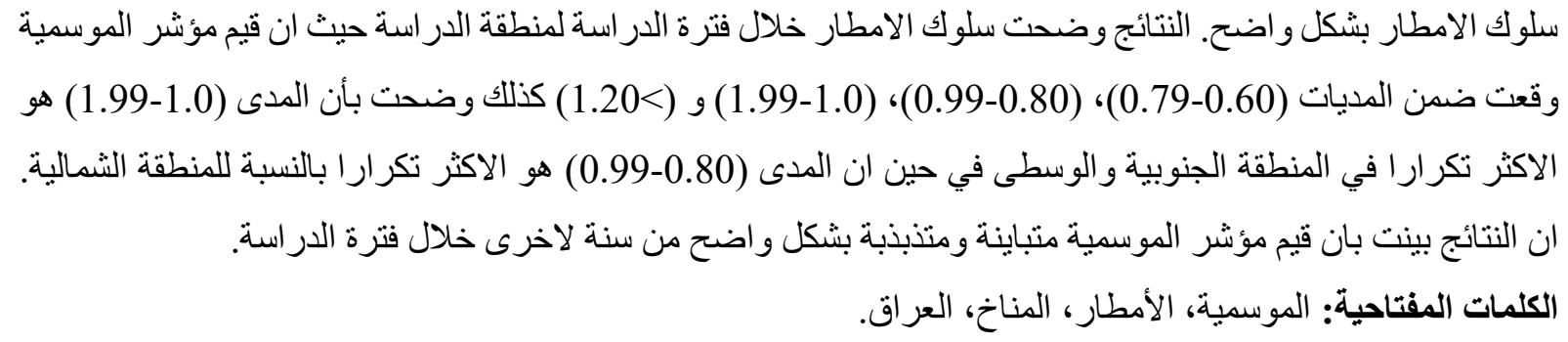

\section{Introduction}

Rainfall is an important climatic variable that is effected by both droughts and floods. To understand the characteristics of temporal and spatial of rainfall, many researchers interest about planning of water resources and management, hydrological modeling, flood frequency analysis, flood hazard mapping, agricultural planning, climate change impacts, water resource assessments, and other environmental assessments. In addition, many studies deal with Rainfall seasonal index that helps researchers to describe the features of distribution precipitation and estimation of future. Although, Ramage (1971) [1], Jackson (1977) [2] and Nieuwolt (1977) [3] characterize seasonality of rainfall in qualitative terms, the estimation by Walsh and Lawler 1981[4] of Seasonality Rainfall Index is a basic of most studies. Rainfall seasonality is a complicated_notion which integrates a numeral of independent components (Walsh \& Lawler 1981) [4]. Seasonality estimates the seasonal variances of rainfall amounts, and not wetness or dryness in an absolute sense Livada and Asimakopoulos [5]. The aims of seasonality index are description characterize the distribution of precipitation of selected year or period and classification of climate of an area. (M.K.Patil)[6]. The changing in the seasonal rainfall has greatly effect on runoff, evapotranspiration and infiltration, although, the changing in annual total rainfall could be absence which effects on responsibility of ecosystem, stream discharge and flood forecasting [7,8,9,10,11,12,] [Epstein et al., 2002; Groisman et al., 2001; Rosenberg et al., 2003; Small et al., 2006; Xiao and Moody, 2004]. Livada and Asimakopoulos determine the correlation of the average individual seasonality index with the seasonality Index initially, examined the time series trend of the seasonality index and they found there is no significant change in rainfall seasonality occurred [5]. P. Guhathakurta and Elizabeth S., studied a long rainfall data series (1901-2006) of districts of Maharashtra to get the spatial pattern and 


\section{Analysis of Rainfall Seasonality Index in Iraq}

\section{Hasanain K. A. AL-Shamarti}

variability by analyzing mean rainfall and coefficient of variability that performed by monthly and seasonal scales. Then identified the long term changes of the seasonality index by the trend analysis of scarcity in Maharashtra [13]. G. Sumner et al., 2001 used monthly precipitation values for 410 sites for 1964-1993 and calculated the seasonality index of Rainfall in eastern and southern coastal Spain and compared between southern and eastern areas [14]. Sharma, A. and Bose, M. Evaluated seasonal factors and predict the amount of quarterly rainfall in Kolkata based on the past dataset using Regression Model and uses the estimated values with the actual observations to make comparison [15].

In this paper we attempt to give description about dominant behavior precipitation by seasonality index and divided the study area to three zone according to amount rainfall to give understandable conception of rainfall regime then compare among them to select which range of $R S I$ is more frequency which give understandable description of rainfall distribution.

\section{Data and methodology}

\subsection{Data Acquisition}

Historical records of monthly rainfall data for the time period 1980-2010 were acquired from the Iraqi meteorological origination and seismology (IMOS). The long-term data collected for 28 weather stations at different region of the country. The missing data was obtained and the average of the monthly rainfall of studied stations are calculated. Figure 1 shows geographical location of stations and table 1 gives the description of the stations. 
Analysis of Rainfall Seasonality Index in Iraq

Hasanain K. A. AL-Shamarti

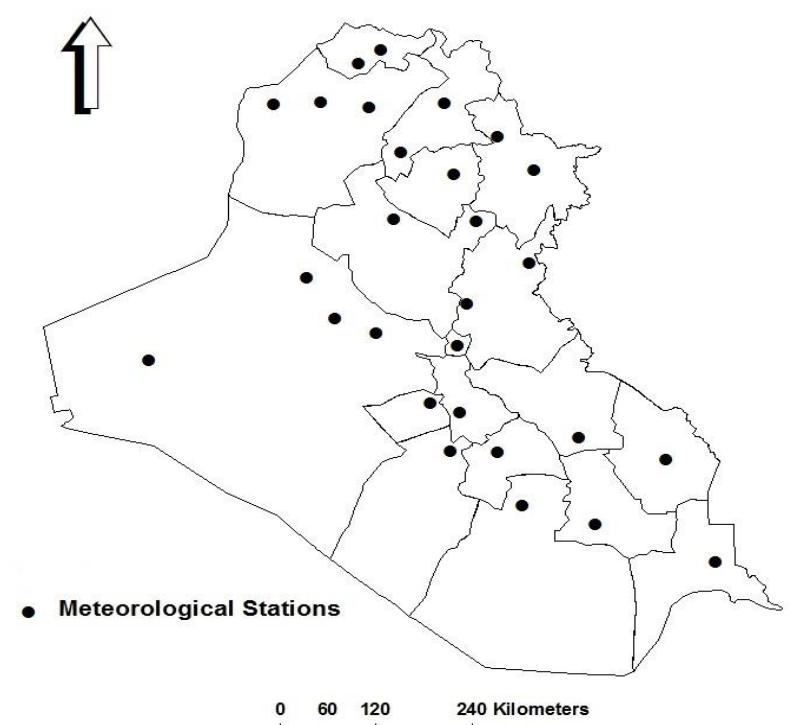

Figure1: Map of Meteorological stations of area study

Table 1: Iraqi meteorological stations

\begin{tabular}{|c|c|c|c|c|}
\hline NO. & Stations & Longitude & Latitude & Elevation (Meter) \\
\hline 1 & Emadiyah & 43.30 & 37.05 & 1236 \\
\hline 2 & salahaddin & 44.20 & 36.38 & 1075 \\
\hline 3 & Sulaymaniyah & 45.45 & 35.53 & 843 \\
\hline 4 & Sinjar & 41.83 & 36.32 & 583 \\
\hline 5 & Duhook & 43.00 & 36.87 & 554 \\
\hline 6 & Teleafer & 42.48 & 36.37 & 373 \\
\hline 7 & Kirkuk & 44.35 & 35.47 & 331 \\
\hline 8 & Dukan & 44.95 & 35.95 & 276 \\
\hline 9 & Mosul & 43.15 & 36.31 & 223 \\
\hline 10 & Rutba & 40.28 & 33.03 & 222 \\
\hline 11 & Tuz & 44.65 & 34.88 & 220 \\
\hline 12 & Khanqin & 45.38 & 34.35 & 202 \\
\hline 13 & Biji & 43.53 & 34.9 & 116 \\
\hline 14 & Hadithah & 42.35 & 34.13 & 108 \\
\hline 15 & Heet & 42.75 & 33.63 & 58 \\
\hline 16 & Najaf & 44.32 & 31.95 & 53 \\
\hline 17 & Ramadi & 43.32 & 33.45 & 48 \\
\hline 18 & Khahlis & 44.53 & 33.83 & 44 \\
\hline 19 & Baghdad & 44.40 & 33.3 & 29 \\
\hline 20 & Kerbela & 44.05 & 32.57 & 27 \\
\hline 21 & Hella & 44.45 & 32.45 & \\
\hline & & & & 32 \\
\hline
\end{tabular}




\title{
Analysis of Rainfall Seasonality Index in Iraq
}

\author{
Hasanain K. A. AL-Shamarti
}

\begin{tabular}{|c|c|c|c|c|}
\hline 22 & Makhmoor & 43.60 & 35.75 & 22 \\
\hline 23 & Diwaniya & 44.95 & 31.95 & 20 \\
\hline 24 & Hai & 46.03 & 32.13 & 17 \\
\hline 25 & Samawa & 45.27 & 31.27 & 11 \\
\hline 26 & Amara & 47.17 & 31.83 & 9 \\
\hline 27 & Nasiriya & 46.23 & 31.02 & 5 \\
\hline 28 & Basrah & 47.78 & 30.52 & 2 \\
\hline
\end{tabular}

According to the precipitation of meteorological stations of Iraq, the area study can be divided into three major zones : Northern zone includes ( Dukan, Duhook, Emadiyah , Khanqin , Kirkuk, Makhmoor, Mosul, Salahaddin, Sinjar, Sulaymaniyah, Teleafer and Tuz ). Middle zone includes (Amara, Baghdad, Basra, Biji, Hadithah, Hai, Heet, Khalis and Ramadi). Southern zone includes (Diwaniya, Hella, Kerbela, Najaf, Nasiriya, Rutba and Samawa). [16]

\subsection{Climate of Study Area}

The climate of Iraq is generally as continental and subtropical semi-arid type whereas the mountainous regions that are north-eastern and north are classified a Mediterranean climate. The occurrences of rainfall are in the winter from October to May. The mean annual is estimated at $216 \mathrm{~mm}$, but in the northeast, the ranges of rainfall graded from $1200 \mathrm{~mm}$ to less than 100 $\mathrm{mm}$ which covers $60 \%$ of south of Iraq. The winter season is cool and sometimes very cold with daily temperature approximates to $16{ }^{\circ} \mathrm{C}$ and falls down to $2{ }^{\circ} \mathrm{C}$ which happens at night and sometimes the frost occurs. However, the summer season is dry and hot (sometimes extremely hot), with over $43{ }^{\circ} \mathrm{C}$ of a shade temperature in July and August, yet reaches to 26 ${ }^{\circ} \mathrm{C}$ at night. The agro-ecological zones are four parts of climate of Iraq that is divided into [17]: Arid and semi-arid that cover the northern zone stations with a Mediterranean climate. The annual winter rainfall is over $400 \mathrm{~mm}$ and a growing season of about nine months also have mild/warm summer prevail. Wheat, barley, rice and chickpea are major crops in this zone. In addition, the productions of other field crops are smaller quantities. Steppes zone, in winter, the annual rainfall in range $200-400 \mathrm{~mm}$ with cold weather whereas, summer season is extremely hot. This zone is located between Desert and Mediterranean zones which has areas that produce feed barley and wheat. Desert zone has extreme temperatures in summer season and the rainfall in winter season at $200 \mathrm{~mm}$ and less annually. The location of this zone in middle of Iraq which expands from Baghdad's north to Saudi Arabian and Jordanian's borders. The irrigated area 


\section{Analysis of Rainfall Seasonality Index in Iraq}

\section{Hasanain K. A. AL-Shamarti}

extends between the Tigris and Euphrates rivers and from the Baghdad's north to Basra in south. The salinity and poor drainage seriously effect on this zone however the rice and sunflower are produced at most in this area.

\subsection{Calculate Rainfall Seasonality Index $R S I$ :}

The definition of Seasonality index depend on the monthly distribution of rainfall that classify the behavior of rainfall. Therefore, $(R S I)$ could be computed by monthly and annual mean rainfall ${ }^{[4]}$ :

$$
\overline{R S I}=\frac{1}{\bar{P}} \sum_{n=1}^{12}\left|p_{n}-\frac{\bar{P}}{12}\right| \ldots \ldots 1
$$

Where $p_{n}$ is the rainfall of $n$ month and $\bar{P}$ is the annual average of rainfall. Theoretically, if the months of year have equal amount rainfall or the rainfall occurs in one month, the Seasonality index has variance from zero to 1.83 . Table 2 explain the different classification of SI and rainfall behavior [18]. In spite of the usage of monthly distribution of rainfall during year, the Seasonality index explains the seasonal behavior when the value of it is more than 0.6.

Table 2: Classification of Seasonality Index.

\begin{tabular}{|c|l|}
\hline RSI & \multicolumn{1}{|c|}{ Rainfall Behavior } \\
\hline$<0.19$ & Rainfall spread throughout the year \\
\hline $0.20-0.39$ & Rainfall spread throughout the year, but with a definite wetter season \\
\hline $0.40-0.59$ & Rather seasonal with a short drier season \\
\hline $0.60-0.79$ & Seasonal \\
\hline $0.80-0.99$ & Markedly seasonal with a long dry season \\
\hline $1.00-1.19$ & Most rainfall in less than 3 months \\
\hline$>1.20$ & Extreme seasonality, with almost all rainfall in 1-2 months \\
\hline
\end{tabular}

\section{Results and Analyses}

The change of Rainfall Seasonality Index depend on the variation of amount Rainfall therefore the fluctuations are clear in figures. Figure 2 shows the Rainfall Seasonality Index at the stations in the northern zone of the country. Emadiah and Duhook stations were at same time of maximum and minimum values that were noticed at 1995 and 1984 respectively. 


\section{Analysis of Rainfall Seasonality Index in Iraq}

\section{Hasanain K. A. AL-Shamarti}

However, the maximum RSI of Emadiah was discriminated in range $(1.20<)$ whereas, $R S I$ of Duhook changed its behavior from range (0.80-0.99) to range (1.0-1.19) of end study period due to decrease amount of Rainfall. In similarity, the maximum and minimum RSI of Dukan and Kirkuk satiations were at 1989 and 1993 respectively. Surprisingly, RSI of Dukan steadied in range (0.80-0.99) at last decade of study period, while, $R S I$ values of Kirkuk were unsteadied in middle decade of study period. Also, at 1989, the maximum RSI of Salahaddin and Makhmoor were noticed, however, the minimum RSI of Salaahddin was recorded at 1994 and of Makhmoor at 1993 and 2010. In Salaahddin, RSI distinguished that was stable within ranges (0.80-0.99 and 1.0-1.19) in 1995-2010. Conversely, RSI of Makhmoor was fluctuated and various. Moreover, the Seasonality Index has maximum values of Khanqin, Sinjar and Mosul at 1998, 1980 and 1988 which took place in range (1.20<) and minimum at 2009, 1982 and 1996 respectively that were recognized in range (0.60-0.79). Although, the $R S I$ of Teleafer and Tuz stations was minimum value at 2010, maximum RSI was deferent between them where it could be apparent that the maximum value of Teleafer station happened at 1989 and 1995 whereas the maximum values of Tus station happened at 1998 and 1999. The fluctuation of $R S I$ was very clear in Teleafer station than Tuz. For illustration, at the last decade, the RSI values were noticed in two range in Teleafer station however it was stable at same time in Tuz station. Figure 3 shows the Seasonality Index at the stations in the middle zone of the country. It can be seen that the RSI oscillated from year to year. The minimum values $R S I$ of Baghdad, Basra, Baji, Heet, Khalis, and Ramadi were noticed at 1982 in range (0.80-0.99), exceptionally, Heet an Ramadi were occurred in range (0.60-0.79), whereas, the maximum values $R S I$ of Baghdad, Heet and Ramadi were noticed at 1999 in range $(1.20<)$, also, in the same range, the maximum RSI of Basra was showed at 1998 and at 1989 the peek RSI of Khalis and Baji were noticed. In addition, the maximum and minimum value of $R S I$ of Amara station were recorded at 2001, 1990, Hai station at 1990, 1984 and Hadithah at 1995, 2006 respectively. RSI of Amara slightly increases at end study period that is conversed to starting study period, whereas in Bagdad it is much fluctuated and various also in Basra it is regular in 1987-1997 and jumped at 1998 than fluctuated in end of study period. Baji's RSI slightly increased at starting period to reach the peak, than dropped at 1993 and again increased at middle and end of study period. 


\section{Analysis of Rainfall Seasonality Index in Iraq}

\section{Hasanain K. A. AL-Shamarti}

Heet, Ramadi and Hadithah have same behavior of RSI which increased at starting period then dropped at 1982 (exception Hadithah which has minimum RSI at 2006) then obviously increased and jumped at 1999 and gradually decreased in end of study period likewise RSI of Khalis which slightly decreased as well as it was steady at 1985-1995.

$R S I$ of Hai is the most stable than others, it could be clear the RSI stays steady in starting period then reached to peak at 1990 and again returned to take same range before its jumping at 1998 then dropped to steady at end study period.

Figure 4 shows the Rainfall Seasonality Index at the stations in the southern zone of the country. Diwaniya and Samawa have maximum RSI at1990 in range $(1.20<)$ and minimum at 2006 in range (0.80-0.99) and at 2009 in (0.60-0.79). The maximum RSI of Hella, Najaf and Nasiriyah took place at 2003, 1999 and 1997 in range $(1.20<)$.

In contrast, the minimum $R S I$ of Hella and Najaf are noticed at 1985, 2010 in range (0.60-0.79) and of Nasiriyah at 2003 in (0.80-0.99). Minimum values of RSI of Kerbela and Rutba were at 1982 in range (0.60-0.79) and (0.80-0.99).

Also, the maximum values occurred in deferent years that were 1993 and 1991 in range $(1.20<)$.

The RSI trend of these stations discriminates that is fluctuated and unstable throughout study period. The trend of RSI in Najaf station decreased at last study period convers of starting period likewise Samawa station which has dramatically dropping $R S I$ at end period. Whereas, in spite of fluctuations between RSI's ranges, the trend increased gradually in Kerbela and Rutba at middle study period but at end period the trend decreased. In similarity, Nasiriyah and Hella also slightly increased then at end period drops to change $R S I$ behavior.

The RSI of Diwaniya decreased at starting of period and increased gradually to jump at peak point which occurred at 1990 then steady at middle of period with some fluctuations. 


\section{Analysis of Rainfall Seasonality Index in Iraq}

\section{Hasanain K. A. AL-Shamarti}

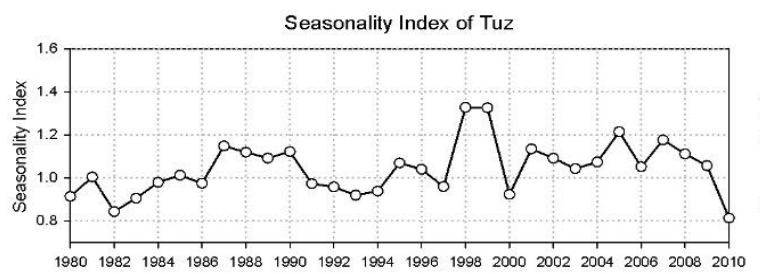

Years

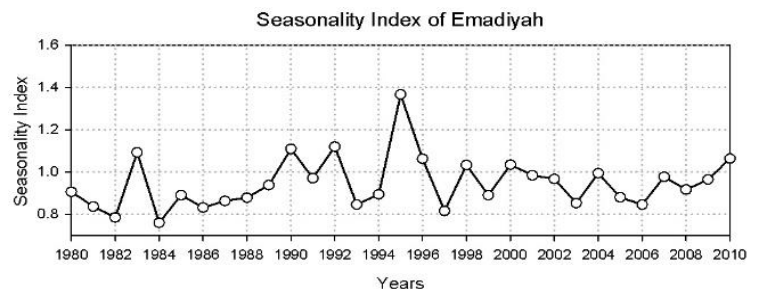
Years
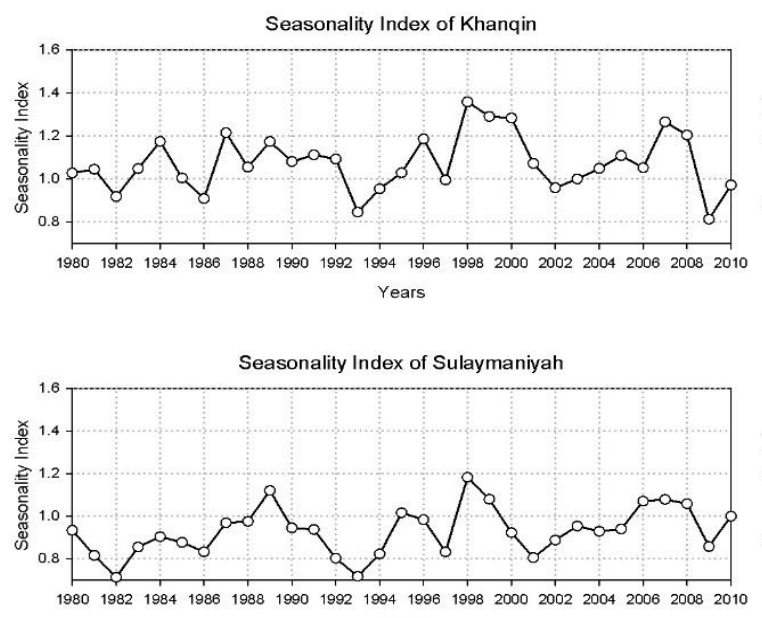

Years

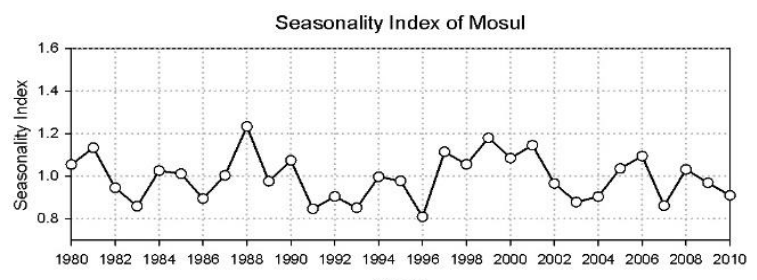

Years

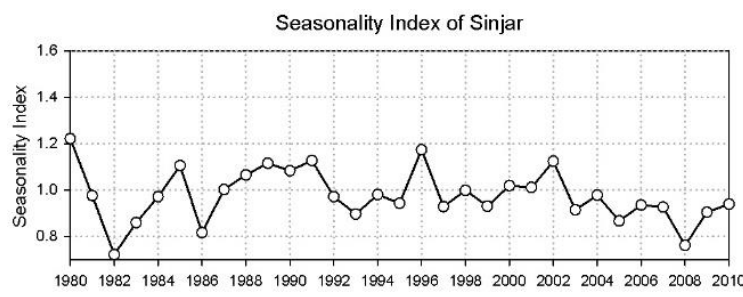

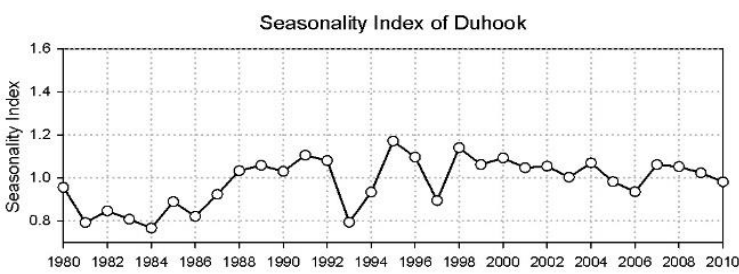

Years
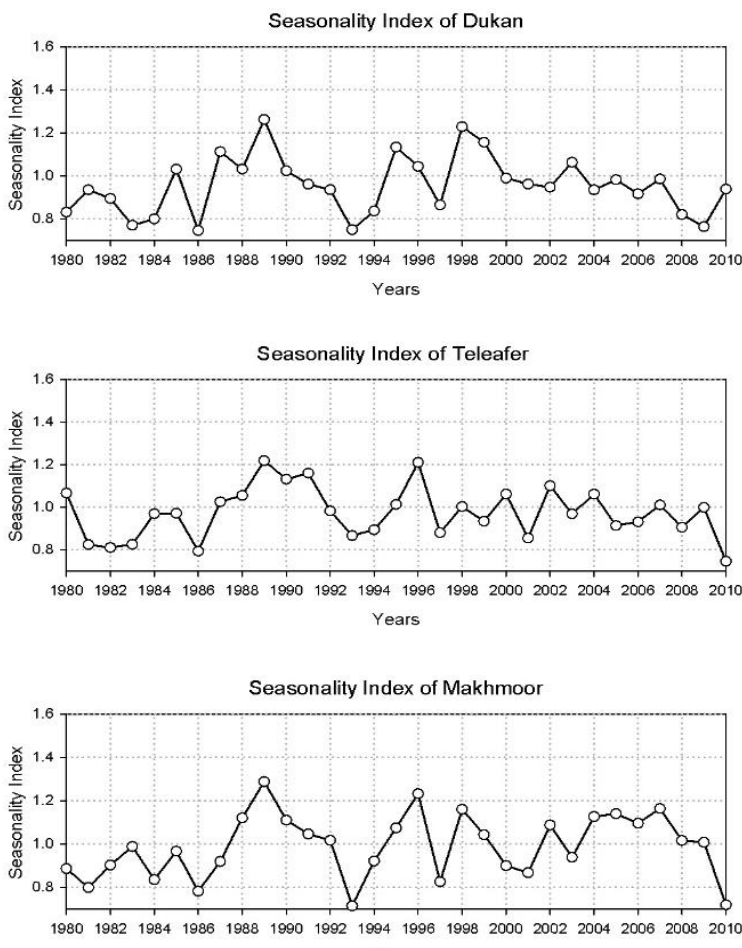

Years

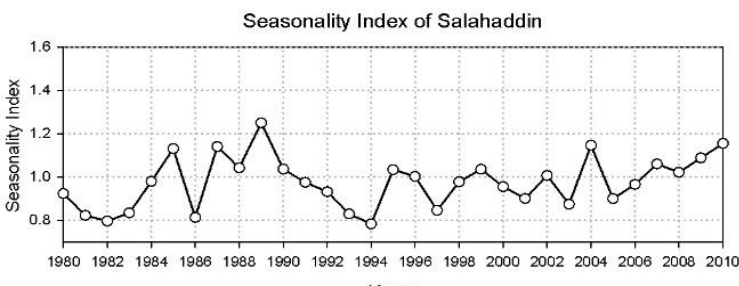

Years

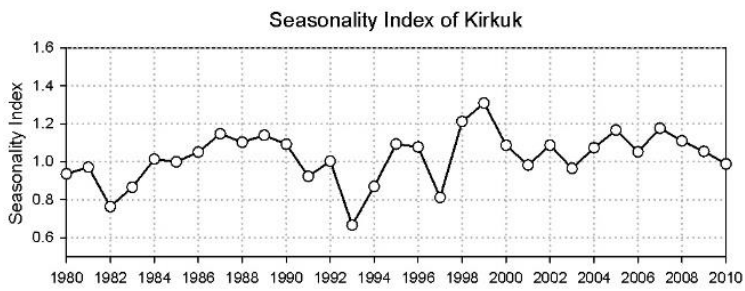

Figure 2: explain the seasonality index of Northern zone of 1980-2010 period 


\section{Analysis of Rainfall Seasonality Index in Iraq}

\section{Hasanain K. A. AL-Shamarti}
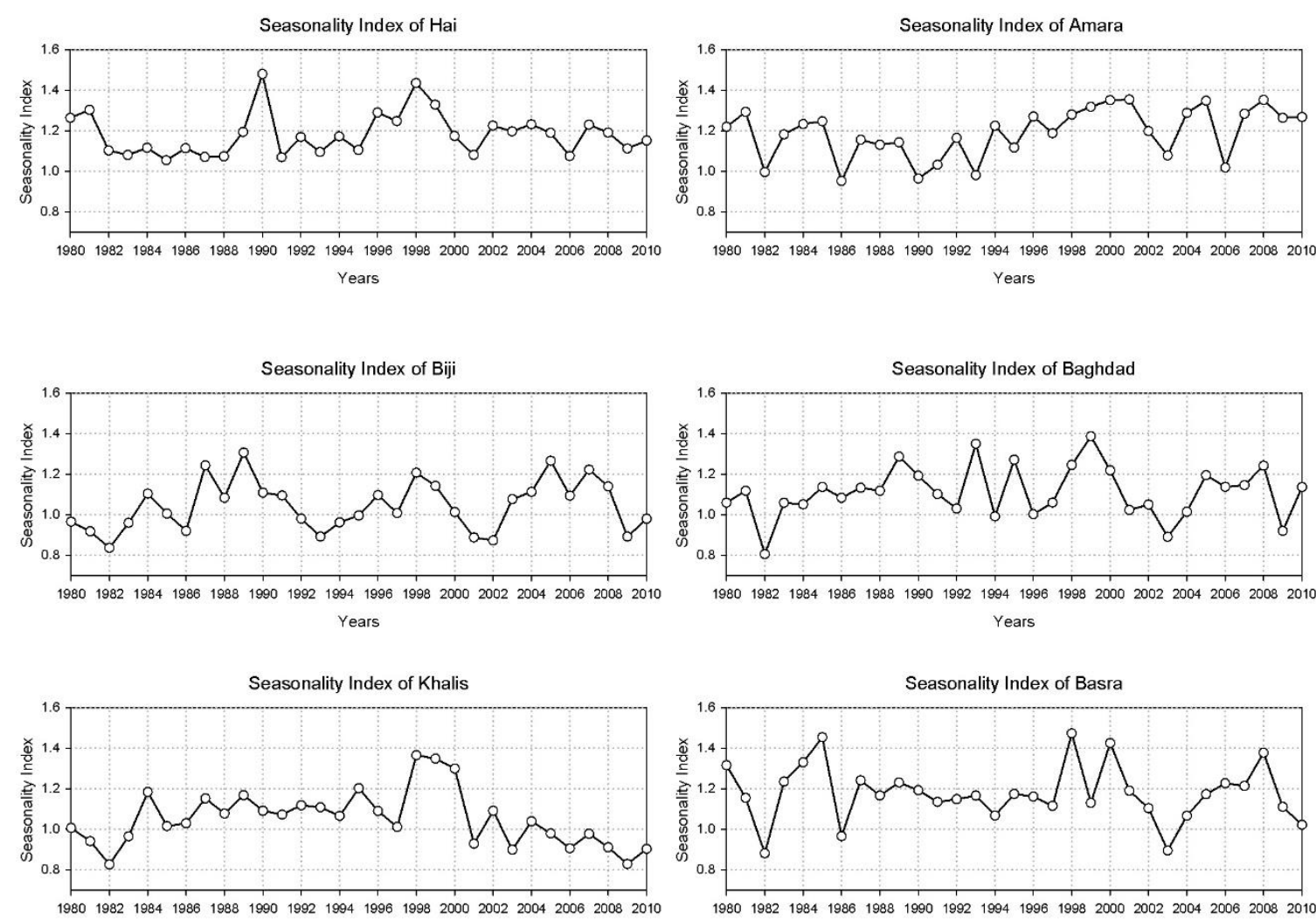

Years
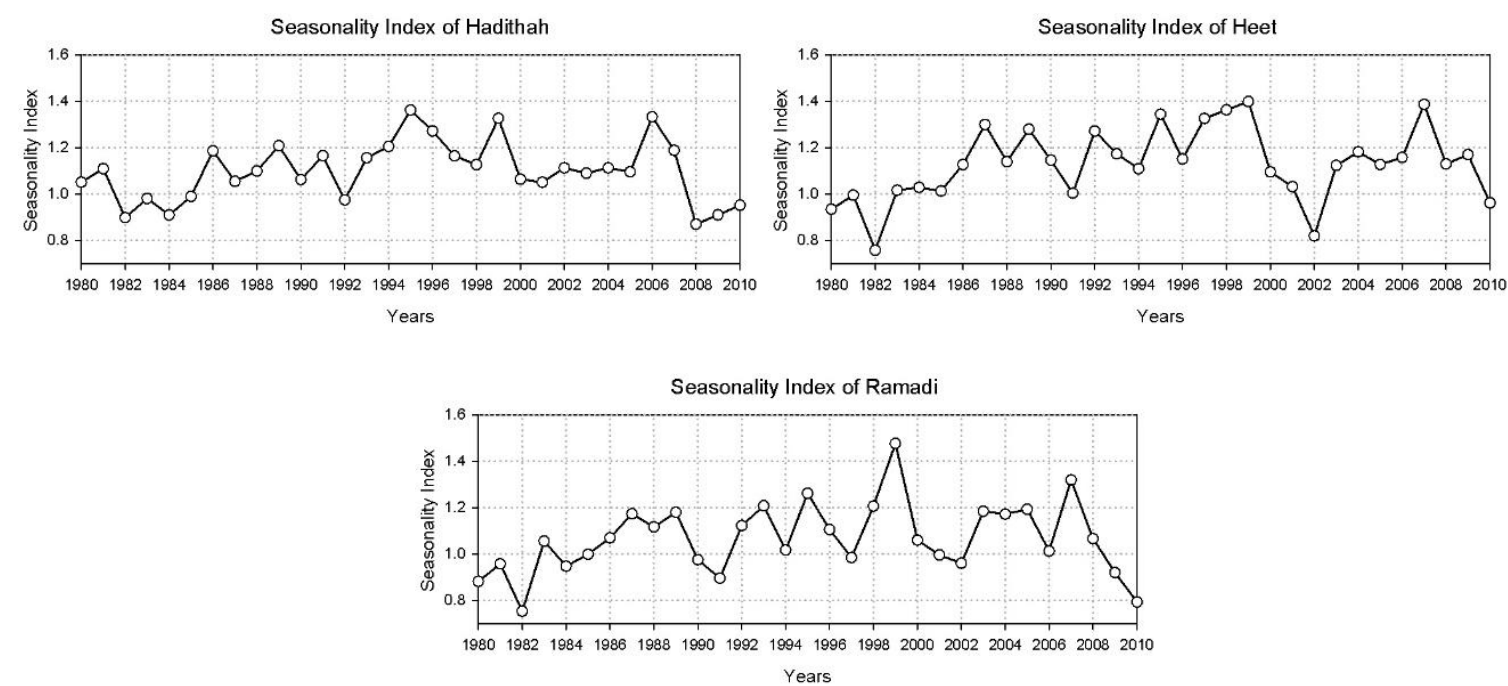

Figure 3: explain the seasonality index of Middle zone of 1980-2010 period. 


\section{Analysis of Rainfall Seasonality Index in Iraq}

\section{Hasanain K. A. AL-Shamarti}
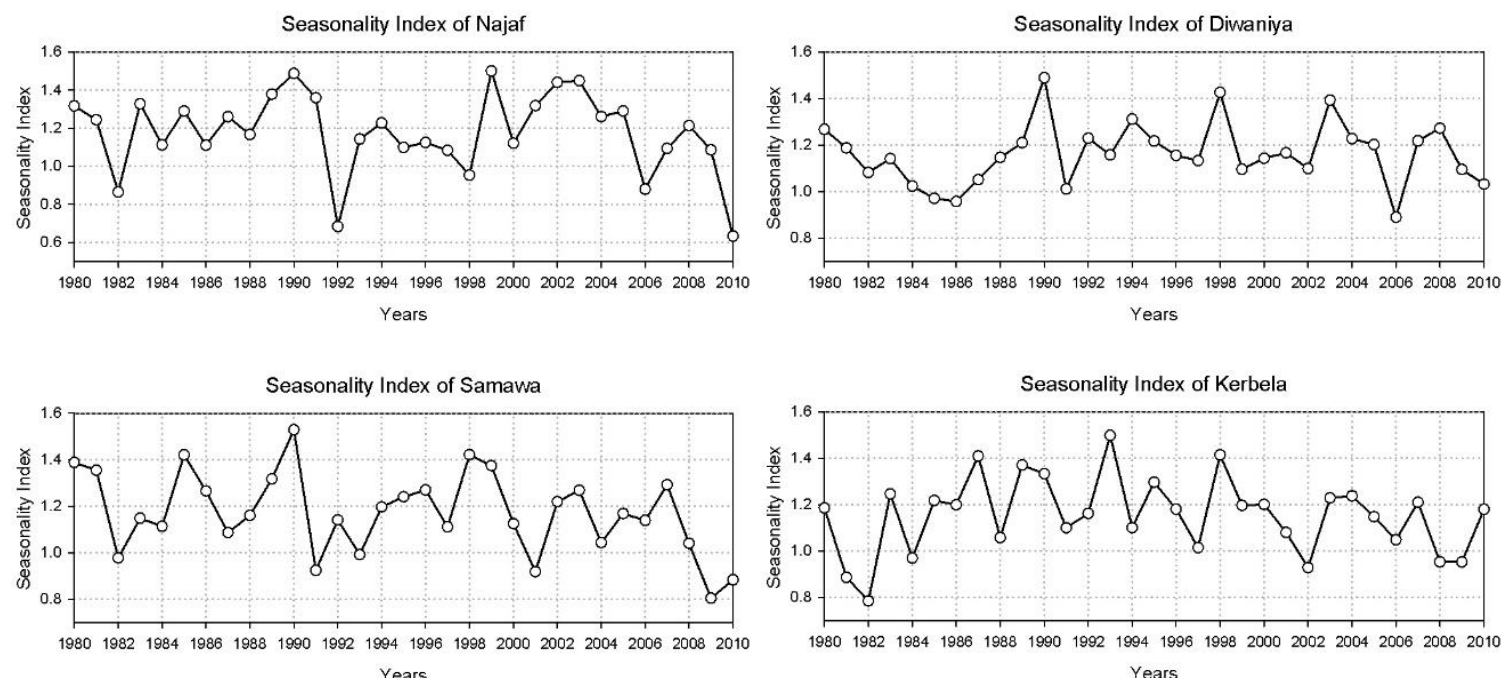

Years
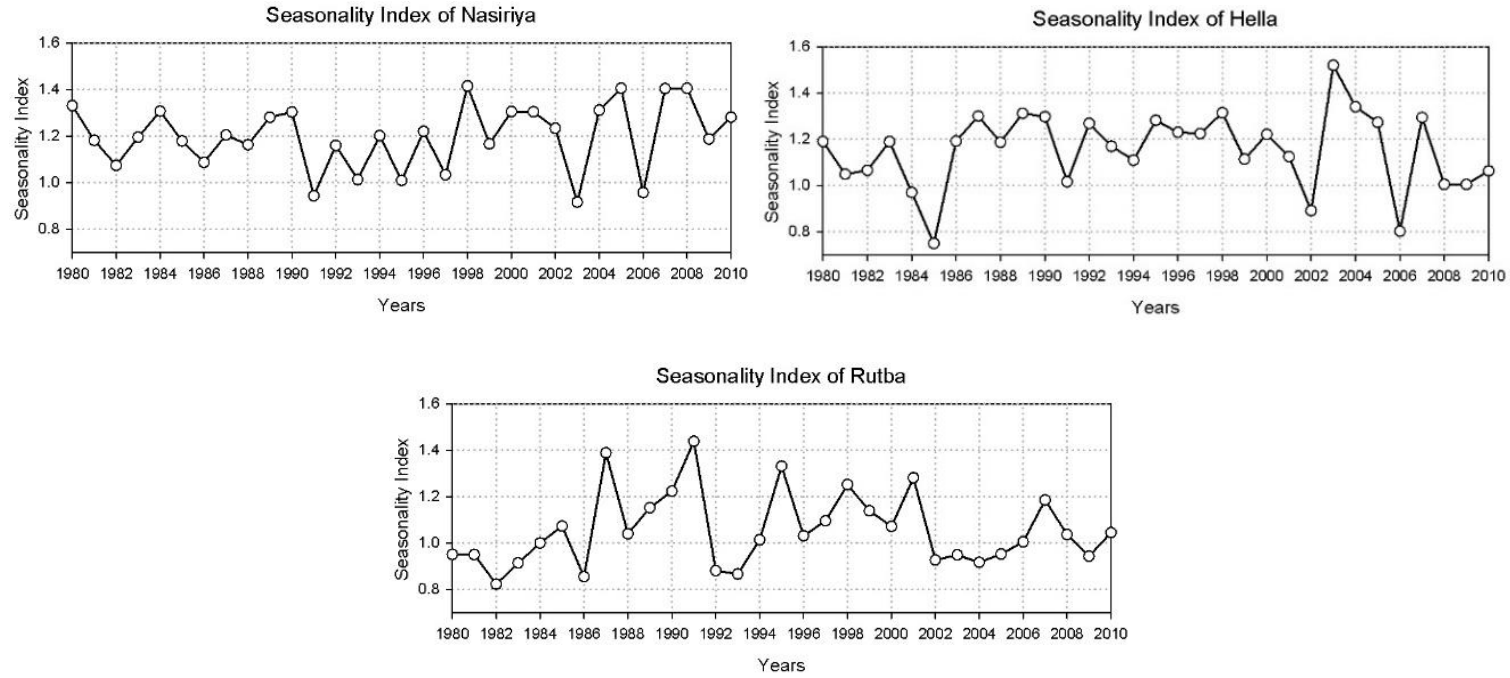

Figure 4: explain the seasonality index of Southern zone of 1980-2010 period.

On the other hand, the frequency of $R S I$ to classifications of $R S I$ were showed in figure 5 where these are important to give information about permanent behavior of rainfall in these area. Obviously, the range (0.80-0.99) of $R S I$ which means markedly seasonal with a long dry season is more frequent than other range in Northern zone, whereas the range (1.0-1.19) which means most rainfall in less than 3 months is prevailing range in Middle and southern zone, however, the range $(1.20<)$ is markedly frequent in southern zone. It was found that the Rainfall Seasonality Index of Iraq takes values among four ranges which are (0.60-079), (0.80-0.99), 


\section{Analysis of Rainfall Seasonality Index in Iraq}

\section{Hasanain K. A. AL-Shamarti}

$(1.0-1.99)$ and $(1.20<)$ and the range (1.0-1.99) is more frequency from others for all study area but in northern zone the range $(0.80-0.99)$ is highest one.

That's means, the rainfall of Iraq is extreme seasonality and fluctuated, thus, the dominant behavior of rainfall refers to most of rainfall of Iraq falls in three months with a long dry season.
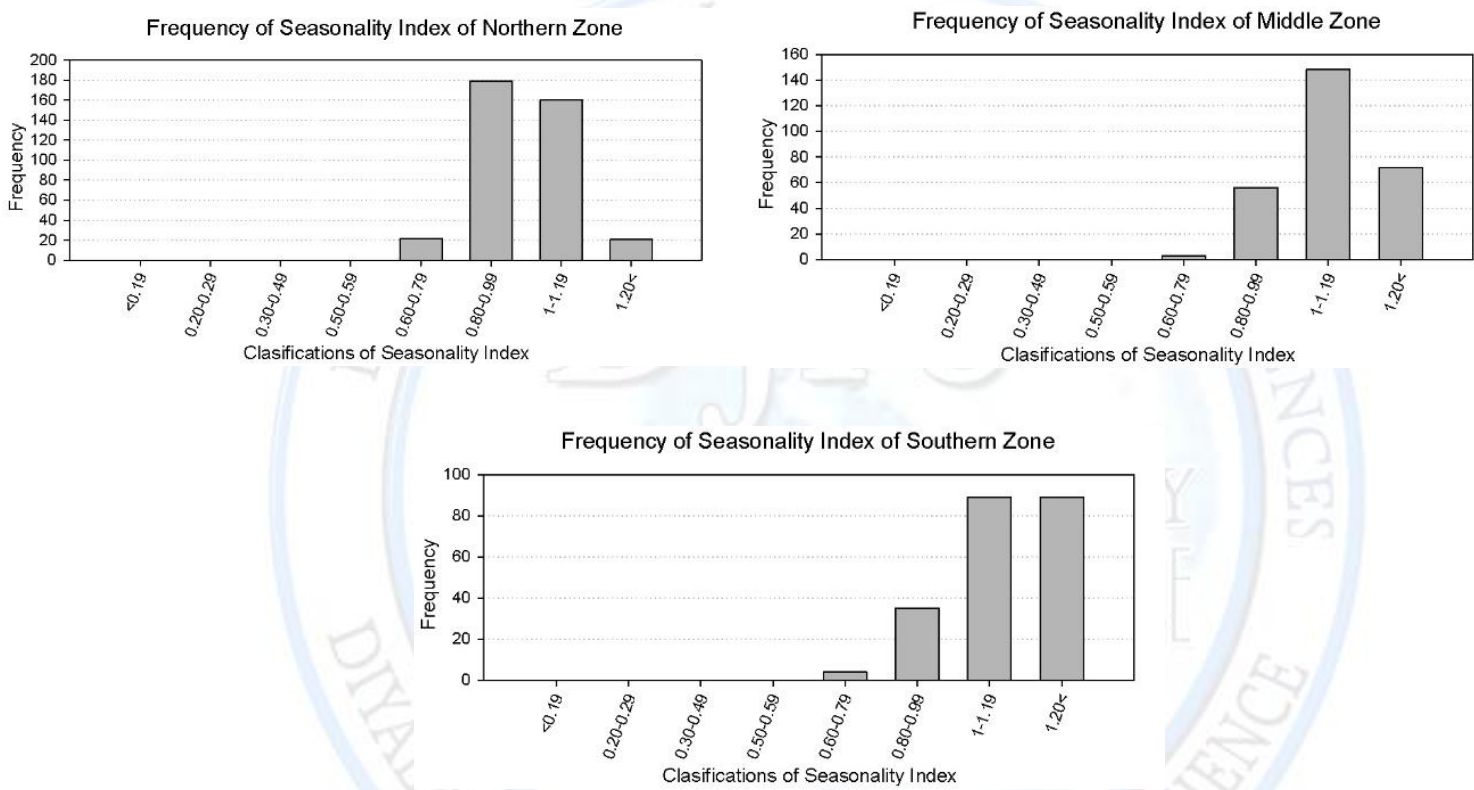

Figure 5: explain the frequency of Seasonality Index.

\section{Conclusions}

The results shows that the Rainfall seasonality index $(R S I)$ of the study area was notable variation and obviously fluctuations from year to year through the study period. The results show that, in the Northern zone, Duhook and Khanqin stations have never recorded the range (0.6-0.79) of $R S I$, also, Mosul and Tuz stations have never recorded the range $(1.20<)$ of $R S I$. On the other hand, in the Middle zone, Only Ramadi and Heet stations have RSI values in range (0.6-0.79). It could be interested that Hai Station are unique where RSI has not values in range 


\section{Analysis of Rainfall Seasonality Index in Iraq}

Hasanain K. A. AL-Shamarti

(0.8-0.99) as well as (0.6-0.79) and it has distinction from other stations that its $R S I$ values are more regular and harmonic. In the Southern zone, Kerbela and Najaf Station are exception from all Southern zone stations which are studied where they have RSI value in range (0.6-0.79) therefore we can say that the precipitation in southern zone consternates in 2-3 months only and the weather have along dry seasons.

\section{$\underline{\text { References }}$}

1. Ramage C.S, Monsoon meteorology, International geophysics series 1971, Academic Press New York, Vol. 15, p259-277.

2. Jackson I.J, water and agriculture in the tropics Climate, Agricultural Water Management 1977, Longmans, London, Vol.1, No.4, p358-360.

3. Nieuwolt S, Tropical climatology, Quarterly Journal of the Royal Meteorological Society 1977, Wiley, London, Vol.104, No.439, p235-236.

4. Walsh R. P. D. And Lawer D. M., Rainfall seasonality: Description, spatial patterns and change through time, Weather 1981, Vol.36, No.7, p 201-208.

5. I. Livada, D. N. Asimakopoulos, Individual seasonality index of rainfall regimes in Greece 2005, Climate Research Journal, Vol., No.16 p28: 155-161.

6. M. K. Patil, Change in seasonality index of rainfall in Sangli district, Indian Streams Research Journal 2015, Vol.5, No.1

7. Epstein, H. E., R. A. Gill, J. M. Paruelo, W. K. Lauenroth, G. J. Jia, and I. C. Burke, The relative abundance of three plant functional types in temperate grasslands and shrublands of North and South America: Effects of projected climate change, Journal of Biogeography 2002, Vol. 29, No.7, p 875-888.

8. Groisman, P., R. Knight, and T. Karl, Heavy precipitation and high streamflow in the contiguous United States: Trends in the twentieth century, Bull. Am. Meteorol. Soc. Journal 2001, Vol.82, No.2, p219-246

9. Rosenberg, N. J., R. A. Brown, R. C. Izaurralde, and A. M., Thomson Integrated assessment of Hadley Centre (HadCM2) climate change projections on agricultural productivity and irrigation water supply in the conterminous United States. I. Climate 


\section{Analysis of Rainfall Seasonality Index in Iraq}

Hasanain K. A. AL-Shamarti

change scenarios and impacts on irrigation water supply simulated with the HUMUS model, Agricultural and Forest Meteorology. 2003, Vol.117, No. (1-2), p73-96.

10. Small, D., S. Islam, and R. M. Vogel, Trends in precipitation and streamflow in the eastern US: Paradox or perception?, Geophysical Research Letters 2006, Vol. 33, No.3.

11. Xiao, J. F., and A. Moody, Photosynthetic activity of US biomes: Responses to the spatial variability and seasonality of precipitation and temperature, Global Change Biology 2004, Vol.10, No.4, p437-451.

12. S C. Pryor and Justin T. Schoof, Changes in the Seasonality of Precipitation over the Contiguous USA, Journal of Geophysical Research 2008, VOL. 113No.D21.

13. P. Guhathakurta and Elizabeth S., Detecting changes in rainfall pattern and seasonality index vis-`a-vis increasing water scarcity in Maharashtra, Journal of. Earth System Science 2013, Vol.122, No. 3, pp. 639-649.

14. G. Sumner, V. Homar and C. Ramis, Precipitation Seasonality in Eastern and Southern Coastal Spin, International Journal of Climatology 2001, Vol. 21, No. 2 p 219-247.

15. Sharma, A. Bose, M.: Seasonality and rainfall prediction. In Seventh International Conference on Data Mining and Warehousing (ICDMW) 2013, pp. 145-150, Bangalore.

16. Shubber, R. M., Climate variation indices of Iraq, M.Sc. thesis, collage of Science, AL-Mustansiriyah University, Iraq (in Arabic).

17. FAO., Towards sustainable agricultural development in Iraq: The Transition from Relief, Rehabilitation and Reconstruction to Development 2003, p222.

18. E. A. Kanellopoulou, Spatial distribution of rainfall seasonality in Greece, Weather 2002 Vol. 57, No. 6, p215-219. 